\title{
Preparing to Submit a License Application for Yucca Mountain
}

MOL. 20050412.0124

\author{
W. John Arthur ${ }^{1}$ and Michael D. Voegele ${ }^{2}$ \\ 'Director, Office of Repository Development, U. S. Department of Energy, \\ and, ${ }^{2}$ Bechtel-SAIC, LLC; Las Vegas, NV
}

\section{Introduction}

In 1982, the U.S. Congress passed the Nuclear Waste Policy Act, a Federal law that established U.S. policy for the permanent disposal of spent nuclear fuel and high-level radioactive waste. Congress amended the Act in 1987, directing the Department of Energy to study only Yucca Mountain, Nevada as the site for a permanent geologic repository. As the law mandated, the Department evaluated Yucca Mountain to determine its suitability as the site for a permanent geologic repository. Decades of scientific studies demonstrated that Yucca Mountain would protect workers, the public, and the environment during the time that a repository would be operating and for tens of thousands of years after closure of the repository. A repository at this remote site would also: preserve the quality of the environment; allow the environmental cleanup of Cold War weapons facilities; provide the nation with additional protection from acts of terrorism; and support a sound energy policy. Throughout the scientific evaluation of Yucca Mountain, there has been no evidence to disqualify Yucca Mountain as a suitable site for the permanent disposal of spent nuclear fuel and high-level radioactive waste.

Upon completion of site characterization, the Secretary of Energy considered the results and concluded that a repository at Yucca Mountain would perform in a manner that protects public health and safety. The Secretary recommended the site to the President in February 2002; the President agreed and recommended to Congress that the site be approved. The Governor of Nevada submitted a notice of disapproval, and both houses of Congress acted to override the disapproval. In July 2002, the President's approval allowed the Department to begin the process of submittal of a license application for Yucca Mountain as the site for the nation's first repository for spent nuclear fuel and high-level radioactive waste.

Yucca Mountain is located on federal land in Nye County in southern Nevada, an arid region of the United States, approximately 100 miles (160 kilometers) northwest of Las Vegas (Figure 1). The location is remote from population centers, and there are no permanent residents within approximately 14 miles $(23 \mathrm{~km}$ ) of the site. Overall, Nye County has a population density of about two persons per square mile (two persons per 2.5 square $\mathrm{km}$ ); in the vicinity of Yucca Mountain, it is significantly less.

Yucca Mountain is a series of north-south-trending ridges extending approximately 25 miles (40 $\mathrm{km}$ ), and consists of successive layers of fine-grained volcanic tuffs, millions of years old, underlain by older carbonate rocks. The alternating layers of welded and nonwelded volcanic tuffs have differing hydrologic properties that significantly impact the manner in which water moves through the mountain. The repository horizon will be in welded tuff located in the unsaturated zone, more than 1,000 feet (300 meters) above the water table in the present-day climate, and is expected to remain well above the water table during wetter future climate 
conditions. Future meteorology and climatology at Yucca Mountain are important elements in understanding the amount of water available to potentially interact with the waste.

\section{Surface Facilities}

The surface facilities support the operations necessary to receive, stage, age, package, and support emplacement of waste. Figure 2 illustrates three types of Waste Handling Facilities, namely, the Fuel Handling Facility (FHF), the Canister Handling Facility (CHF), and the two Dry Transfer Facilities (DTF), as well as process support facilities.

Inside each Waste Handling Facility, operations will be performed remotely from shielded galleries. Operators will use closed-circuit television or direct observation through shielded windows to control manual and power manipulators, overhead bridge cranes, Spent Nuclear Fuel (SNF) transfer or handling machines, and other remote equipment to perform SNF and High Level Waste (HLW) handling functions. Thick, reinforced concrete walls will shield workers from exposure to radiation and radioactive material.

The Fuel Handling Facility will be the initial facility in operation to receive waste. SNF and HLW contained within the transportation casks will be transferred into waste packages for subsurface emplacement or transferred into site-specific casks for movement to an aging pad. The Fuel Handling Facility will be designed to receive a variety of waste forms, including uncanistered commercial SNF; canistered commercial SNF; canistered naval SNF; canistered HLW; and canistered Department of Energy SNF.

Sealed canisters containing SNF or HLW will be transferred from transportation casks to waste packages in the Canister Handling Facility for emplacement underground or to site-specific casks for aging or staging, if needed. The facility will be designed to handle only waste contained in sealed canisters, typically HLW canisters, Department of Energy SNF canisters, naval SNF canisters, and canisters containing commercial SNF.

The transfer of SNF and HLW from transportation casks to waste packages or to site-specific casks eventually will be accomplished in two Dry Transfer Facilities. The Dry Transfer Facilities also handle off-normal, damaged and nonstandard fuel, damaged transportation casks and damaged waste packages. Both Dry Transfer Facilities provide space, layout, structures, and systems that support waste handling and remediation operations.

SNF will be aged if emplacement must be delayed because of thermal management considerations, including blending to meet waste package thermal limits. Loaded site-specific casks will be moved to concrete aging pads and later retrieved so that their contents may be transferred into waste packages. Space will be provided for initial and future aging capability.

\section{Subsurface Facilities}

The repository subsurface components include the facilities necessary to transport and emplace waste packages. These subsurface facilities include excavated drifts, rail lines, emplacement pallets, engineered inverts, and support systems. The emplacement drifts will be large circular tunnels, nominally 18 feet ( 5 meters) in diameter, used to provide emplacement for about 11,000 waste packages. The total subsurface emplacement area required to accommodate the waste 
packages containing 70,000 metric tons $^{1}$ will be about 1,250 acres ( 500 hectares). This area will include more than 40 miles $(26 \mathrm{~km})$ of emplacement drifts excavated by tunnel boring machines. Ground support will be installed behind the tunnel boring machines to provide structural support and worker protection. The emplacement drift inverts will consist of engineered steel structures and granular fill materials at the base of the emplacement drifts. The inverts will support the pallets, waste packages, drift rail system, and drip shields. The granular material will slow the movement of radionuclides into the host rock in the event that a waste package is breached.

The waste package consists of two concentric cylinders into which the waste forms will be placed. The inner cylinder will be made of stainless steel. The outer cylinder will be made of a corrosion-resistant nickel-based alloy. The closure end of the waste package has three lids that provide a leak-tight closure. The basic waste package design is the same for all waste forms; however, the sizes and internal waste package configurations will vary to accommodate the different waste forms. Before the inner vessel is sealed, air and vapor will be evacuated, and helium added as a fill gas. A pallet in the emplacement drift will structurally support the waste package. Emplacement pallets will be fabricated from the same materials as the waste packages, and will themselves be supported by the emplacement drift invert.

After a decision to close the repository is made and approved by the Nuclear Regulatory Commission, titanium drip shields will be installed to protect waste packages from potentially dripping water and rockfall.

\section{Underground Development}

Portions of the subsurface facility have already been constructed during the site characterization phase. These existing facilities will be upgraded to support the construction of the repository or to become integral parts of the repository. The majority of the subsurface facility will be excavated using tunnel-boring machines. Repository emplacement and development activities will occur concurrently; the separate areas will have separate ventilation systems. A pressure differential will ensure that any releases of airborne radioactivity will be confined to the emplacement side of the repository. The underground layout avoids areas of more fractured rock in the south and restricts emplacement to the north to avoid an area where groundwater levels rise at a steeper gradient.

The layout for the emplacement drifts is based on a phased approach to development that supports the start of waste emplacement after a period of initial construction. Concurrent construction and emplacement will continue for a period of about 24 years. The subsurface layout is designed to be constructed in a four-panel sequence (Figure 3) The initial emplacement panel will be located within the central section of the overall layout and uses the existing. Exploratory Studies Facility and the north ramp for access to the repository horizon. The size of the panel is small in comparison to the other panels, and will be developed and commissioned as soon as possible after construction authorization. The general excavation process of a panel will begin with the excavation of the access and exhaust mains followed by the excavation of the ventilation shafts, and finally the turnouts and emplacement drifts. As the emplacement drifts

\footnotetext{
${ }^{1}$ The Nuclear Waste Policy Act prohibits the emplacement of more than 70,000 metric tons until a second repository is licensed. Congress stopped work on the second repository program when it amended the Act in 1987, and directed the Secretary to report to the President and Congress on the need for a second repository.
} 
within a panel become available to accept waste, the emplacement drifts will be isolated from the ongoing development construction by installing isolation barriers.

\section{Operations Period Safety Analysis}

The operational period is anticipated to last for approximately 24 to 50 years, during which wastes will be received at the site and transferred into waste packages that are transported underground and emplaced. The Nuclear Regulatory Commission requires that the waste be able to be retrieved from the repository beginning at any time up to 50 years after emplacement begins.

Assessment of preclosure safety involves identification of essential safety functions needed to assure the health and safety of workers and the public; identification of structures, systems, and components that will be used to implement these essential safety functions; and design criteria employed to achieve high reliability and defense in depth. Safety will be assured if the repository systems prevent the dispersal of unacceptable quantities of radioactive source materials, and prevent excessive radiation doses to workers and the general public. A combination of essential safety functions, including the integrity of radioactive sources, containment and confinement, and filtration will be used to assure safety.

Shielding integrity will be provided by assuring that shield walls and other components remain intact during external initiating events, and also that moveable openings and doorways are interlocked to prevent opening when significant source terms are present on the other side of the moveable shield. Radioactive source term integrity will be provided by assuring that event sequences, which could breach canister or SNF cladding barriers, have been considered and applicable design criteria applied. Confinement integrity requires a combination of assuring, via design and procedural controls, implemented in accordance with applicable design criteria, that the integrity of the preferential airflow paths to the HEPA filters is maintained. This involves assuring structural integrity against external event sequence impacts, and that all vital support systems required to keep air flow through the HEPA filters are provided.

External and internal hazard analyses show that considering all relevant event sequences and their consequences, the Yucca Mountain repository operations facilities can be designed, constructed and operated to ensure that the safety and health of the public and repository workers will be protected.

\section{The Long Term Safety of a Repository at Yucca Mountain}

The safety of a repository at Yucca Mountain will be assured by the performance of the natural and engineered features of the site, acting in concert, to prevent or delay the transport of radioactive materials to where the public could eventually be exposed to them. The Yucca Mountain repository system has three barriers that are relied upon to isolate radioactive wastes: the Upper Natural Barrier, the Engineered Barrier System, and the Lower Natural Barrier. Figure 4 is a schematic representation of the repository system highlighting the three barriers. The Yucca Mountain site's geologic and hydrologic characteristics form effective natural barriers to the flow of water and to the potential movement of radionuclides. The underground environment within the natural setting is conducive to the design and construction of components that prevent or reduce the movement of water or the potential release and transport of 
radionuclides. The waste isolation capability of the natural setting is a function of the favorable characteristics of the geologic units. The capability of the Engineered Barrier System will be achieved by designing components to function in the natural setting of Yucca Mountain, particularly, its unsaturated rock units. The materials in the Engineered Barrier System have been chosen so that the components perform their intended functions for many thousands of years. Each of the barriers in the repository system works individually, and together, to limit the movement of water and the release and movement of radionuclides.

\section{Upper Natural Barrier}

Yucca Mountain is in a semiarid region where precipitation and humidity are low, thus promoting high evaporation rates. The area near Yucca Mountain also is characterized by great depth to the water table. In the vicinity of the repository, the depth of the water table is approximately 2,000 feet ( 600 meters) below the ground surface, allowing the repository itself to be located approximately 1,000 feet (300 meters) above the water table. The topography and surficial soils of Yucca Mountain provide the initial barrier feature that limits the movement of water into the mountain. Runoff, evaporation, and plant transpiration combine to divert water and permit only a small fraction of the already low expected precipitation at the site to infiltrate into the mountain. The climate and infiltration analyses for Yucca Mountain demonstrate that limited infiltration of water into Yucca Mountain is expected for present and future climates. Precipitation falling on Yucca Mountain is expected to remain low, even for the glacial-transition climates that are forecast for most of the next 10,000 years.

The volcanic tuffs in the unsaturated zone above the repository horizon function to prevent or reduce the movement of water through the unsaturated zone and into the emplacement drifts of the repository. The tuffs divert percolating water, damp pulses of infiltration, and have capillary forces that limit seepage into the emplacement drift. Water flow within the nonwelded tuff unit is predominantly in the matrix, and the rock matrix has a large storage capacity. Only a small percentage of the water is expected to pass through fractures, because they are not well connected. The nonwelded tuff unit thus attenuates flow from the overlying welded unit. The welded tuff units that comprise the repository host rock have lower matrix porosity and higher fracture frequency than the overlying nonwelded tuff. Unsaturated flow in the welded units is expected to be primarily through the fractures.

The rate and distribution of seepage into waste emplacement drifts control the amount of water available to contact the Engineered Barrier System. In the unsaturated zone, seepage into the emplacement drifts will be limited because of capillary forces that limit the movement of water into the drift openings. Water is likely to be retained in the small pores and tight fractures of the low-porosity welded tuff, and a substantial fraction of the flow is expected to move around the drift opening and drain through the rock pillars between the drifts. For a period of time, the decay heat of the emplaced waste will be great enough to heat the rock near the emplacement drifts, and the water will be driven away from the emplacement drift wall surfaces.

\section{Engineered Barrier System}

The Engineered Barrier System prevents or substantially reduces the release of radionuclides from the waste. Should the waste packages remain intact for tens of thousands of years as 
expected, none of the waste forms will be exposed to water and no release of radionuclides will occur.

The drip shield will be designed to divert any seepage away from the waste package. It will prevent water from contacting the waste package as long as it remains intact. Similarly, as long as the waste packages are intact, water cannot contact the waste forms. The Zircaloy cladding that encases much of the spent nuclear fuel also will prevent the contact of seepage water with the waste form as long as it remains intact. The corrosion rates for Titanium Grade 7 are expected to be sufficiently low such that none of the drip shields is expected to breach by these mechanisms before 10,000 years. Stress corrosion cracking may occur as a result of rockfall onto the drip shields. The general corrosion rates for Alloy 22 are sufficiently low so that none of the waste packages is expected to breach before 10,000 years. Stress corrosion cracking may occur in the weld regions of some of the waste packages. Mitigation techniques (e.g., laser peening) will be employed to reduce residual stresses below the stress corrosion cracking threshold, but there remains the potential for breaches of some waste packages before 10,000 years. Early failure of some waste packages potentially may occur due to flaws that are undetected during fabrication or as a result of damage during handling. The probability for early failure in this case is likely to be small because of the quality control measures employed.

In the unexpected event that waste packages are breached, the release rate of radionuclides will be limited by the characteristics of the Engineered Barrier System. The release of radionuclides will be first impeded by the rate of degradation of the waste form. Waste form degradation cannot begin until the waste package is breached, which allows air and moisture to enter. Because of the unsaturated environment, the elevated temperatures within waste packages, and the presence of drip shields and waste packages, the amount of water in contact with the waste form is expected to be limited to a thin film that could possibly adsorb on the waste form surface.

Release can only occur if radionuclides are dissolved in water or attached to colloids, and if there are continuous liquid pathways in the waste package, including thin films of water. Advective transport of radionuclides out of the barrier can occur only if there is a liquid flux of water along these pathways and if breaches are sufficiently open to permit flow. The movement of many dissolved radionuclides, including those that are the greatest contributors to the total inventory, will be retarded by sorption on iron corrosion products within the waste package. The retardation depends on the volume of these corrosion products and on the distribution coefficients associated with them. Sorption onto the corrosion products also reduces movement of those radionuclides reversibly attached to colloids in the water. The radionuclide inventory released from the Engineered Barrier System after the waste package is breached will be limited so long as the drip shield remains intact, precluding advective flow out of the waste package and through the invert; in this case, the release will be purely diffusive. The release that could occur in the unlikely event the drip shield is breached, and does not divert seepage away from the waste package, will be greater than the purely diffusive case and depends on the failure characteristics of the waste package. Both diffusive and advective releases have been considered in the evaluation of radionuclide releases from the Engineered Barrier System.

\section{Lower Natural Barrier}

Radionuclides that migrate down through the unsaturated zone to the water table are transported through the saturated zone before they can reach the accessible environment. Groundwater 
below Yucca Mountain is part of the Alkali Flat-Furnace Creek groundwater subbasin within the Death Valley groundwater system. Present-day flow is to the south and east near Yucca Mountain. This southeasterly flow from the site is incorporated into the stronger southward flow east of the Mountain. The saturated zone of the Lower Natural Barrier includes the fractured volcanic rocks from below the repository to approximately 7 to 9 miles (12 to $14 \mathrm{~km}$ ) south of Yucca Mountain and the saturated alluvium to the accessible environment. The movement of radionuclides in the saturated zone will be slow because the velocity of water that can carry them is low, particularly in the alluvium. In addition, several processes cause the movement of radionuclides to be slower compared to the rate of movement of the water.

Flow in the volcanic aquifers will be predominantly in the fractures. Radionuclides can exchange between the fractures and matrix via matrix diffusion. This diffusive exchange results in a slower effective travel velocity for the bulk of the released radionuclides relative to waterflow velocities in the fractures for two reasons. First, the velocity of water in the pores of the matrix will be slower than velocities in the fractures. Second, sorption onto mineral surfaces in the matrix pores will result in even slower movement for those sorbing radionuclides that diffuse into the matrix materials.

Because the alluvial materials are a porous medium, water flow and radionuclide transport occur in intergranular pores. The effective porosity of the alluvium is significantly greater than the fracture porosity of the tuffs. Consequently, pore velocities in the alluvium are expected to be smaller than those in the fractures of the volcanic aquifers. Although matrix diffusion is not considered important in the alluvium, radionuclide movement will be slow because of the low water velocity. In addition, sorption onto minerals in the alluvium results in retardation of the radionuclide movement relative to the water movement in these sediments.

\section{The Environmental Protection Agency Standard}

The Environmental Protection Agency standards for Yucca Mountain after permanent closure address all potential pathways of radiation exposure and limit an individual's annual radiation exposure from all pathways consistent with what the Environmental Protection Agency considers an acceptable risk to society for 10,000 years following closure. The Environmental Protection Agency also set a standard to protect the groundwater around Yucca Mountain. This standard sets specific limits for the concentration of different types of radioactive particles in the groundwater. Further, The Department must assess an inadvertent human intrusion into the repository at some time in the future.

Three scenario classes are considered in the Total System Performance Assessment (TSPA) that is used to evaluate repository performance: the nominal scenario class, which includes consideration of potential early waste package failures; the igneous scenario class, which includes consideration of unlikely volcanic intrusion and eruption, both of which are low probability events; and the seismic scenario class, which includes consideration of waste package mechanical damage associated with a low probability seismic event and unlikely deliquescenceinduced localized corrosion processes. The sum of the mean annual dose estimates for the individual scenario class modeling cases (i.e., the nominal and the disruptive scenario classes) provides an estimate of the mean annual dose for the total system. 
Demonstration of the performance of the repository includes an assessment of the ability of the repository to limit radiological exposures to the reasonably maximally exposed individual for the period after permanent closure in the event of human intrusion into the Engineered Barrier System. The earliest time after disposal that the drip shields and waste package would have degraded sufficiently that a human intrusion could occur without recognition by the drillers would be well after 10,000 years. Because such a human intrusion without recognition is not projected to occur before 10,000 years after disposal, the results of the human intrusion analysis and its bases were included in the Yucca Mountain Environmental Impact Statement, as required.

Demonstration of the performance of the repository also includes compliance with the separate groundwater protection standards. Radionuclide concentrations are calculated by summing the mass of radionuclides reaching the accessible environment in each year for all likely features, events, and processes and dividing that sum by the representative volume of water to calculate the annual radionuclide concentrations.

Calculations performed to date indicate that a repository at the Yucca Mountain site will likely meet all of the Environmental Protection Agency requirements for 10,000 years following permanent closure. The standard also includes a requirement to assess the performance of the Yucca Mountain repository at time of peak dose. This evaluation has been done and the results were reported in the Environmental Impact Statement. However, since that time, a Federal Court has vacated that standard to the extent that it only required compliance for 10,000 years. The Environmental Protection Agency and the Nuclear Regulatory Commission are currently assessing paths forward; their potential actions will have a bearing on the license application process.

\section{The License Application}

Before a repository can be constructed and operations can begin, the Department of Energy first must apply for and receive construction authorization from the Nuclear Regulatory Commission, an independent agency of the federal government. This construction authorization must then be followed by an application for, and receipt of, a license to receive and possess waste. An amendment to the license will be needed to close the repository. The Department is in the process of preparing the license application.

Although the Department of Energy and Nuclear Regulatory Commission are both federal entities, they operate as independent agencies, a relationship that is defined in the Energy Reorganization Act of 1974. This federal law assigns the Nuclear Regulatory Commission the responsibility of regulating the nation's civilian use of nuclear materials to ensure adequate protective measures are in place to protect the public and the environment. The Department of Energy was given the responsibility for promoting nuclear power and conducting other energyrelated work, including the storage and disposal of spent nuclear fuel and high-level waste.

If the Department of Energy is approved to construct and operate a repository at Yucca Mountain, it will become a Nuclear Regulatory Commission licensee and be subject to their regulations in all phases of operation, including receipt and possession of nuclear materials, and transportation of nuclear materials to the repository site. 


\section{Figure Captions}

Figure 1. Location of Yucca Mountain and illustration of access to underground development, with details of emplacement drifts.

Figure 2. Surface facility layout illustrating location and sequencing of processes for waste handling facilities.

Figure 3. Illustration of layout of surface facilities and underground facility, with emplacement sequencing indicated.

Figure 4. Schematic representation of the repository system highlighting the three barriers that are relied upon to isolate radioactive wastes: the Upper Natural Barrier, the Engineered Barrier System, and the Lower Natural Barrier. 


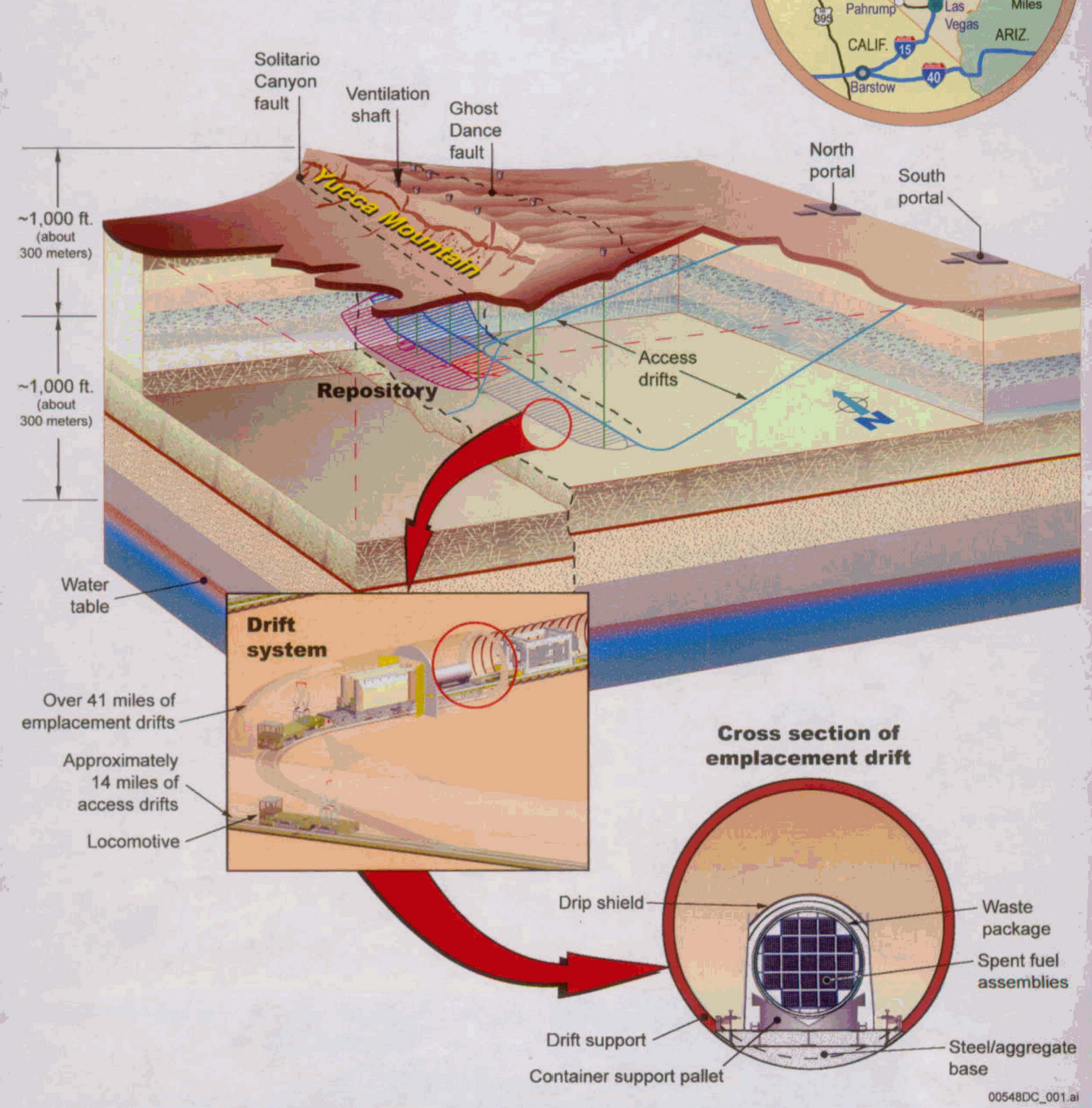




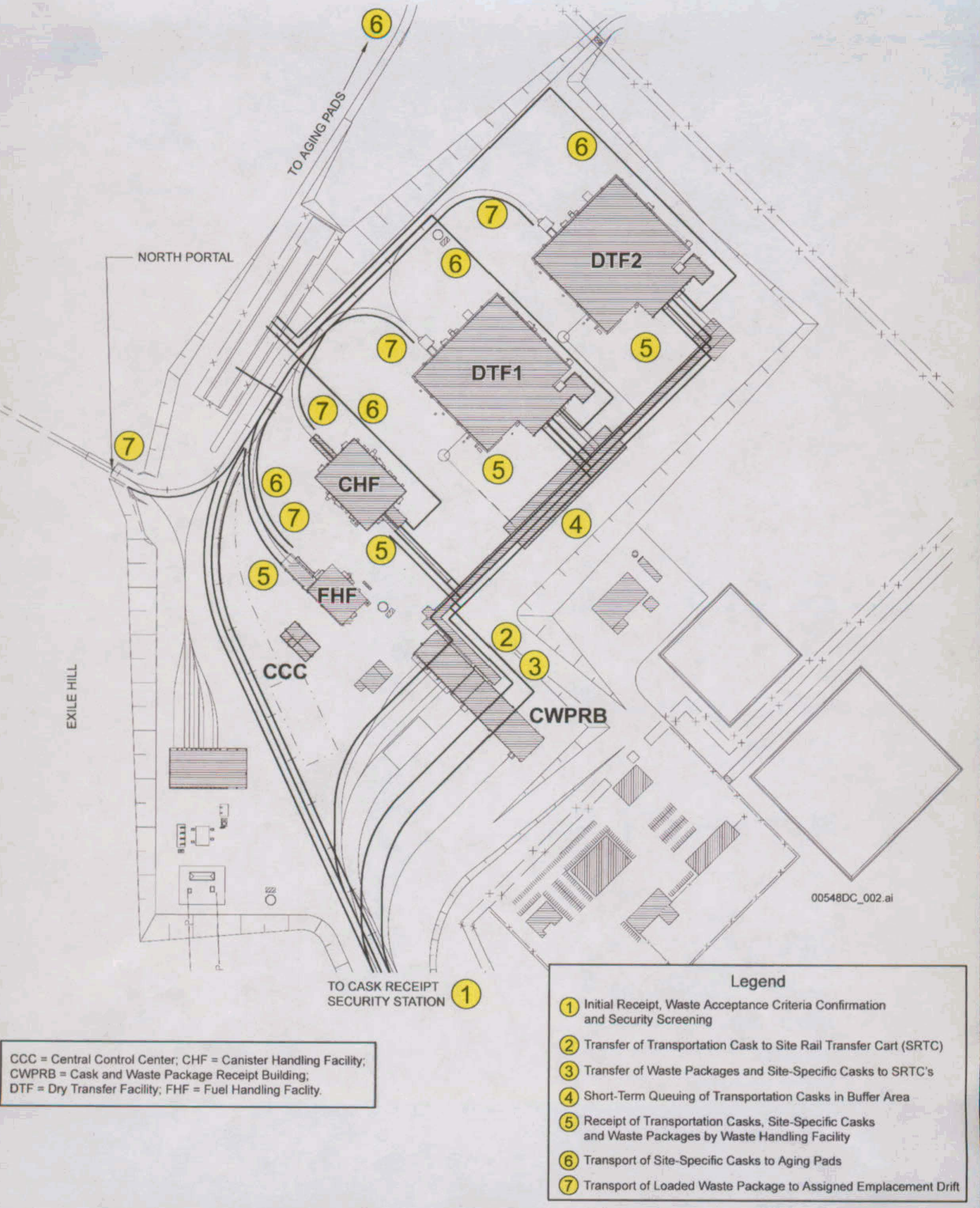




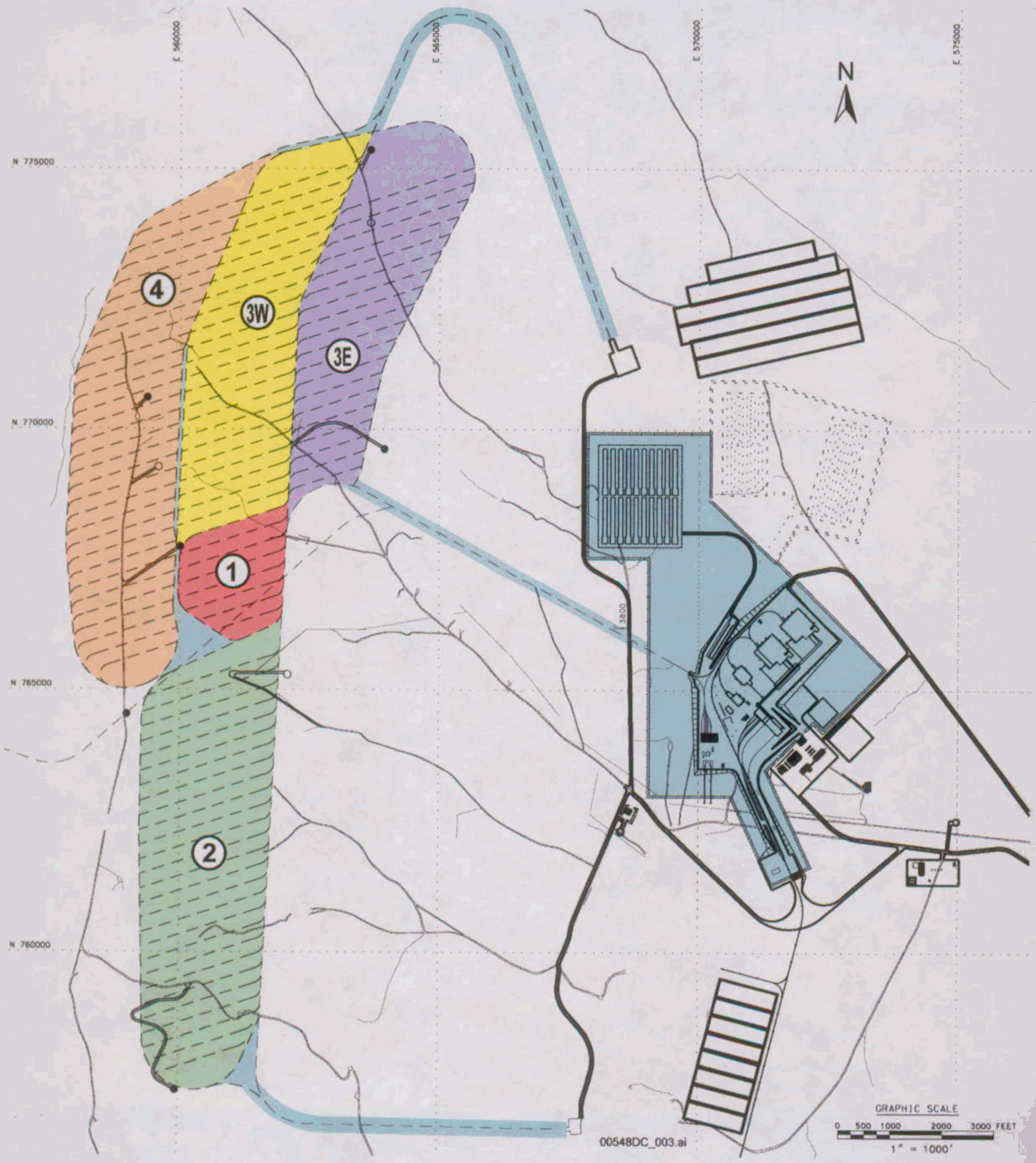




\section{$\triangle$ Arid Environment}

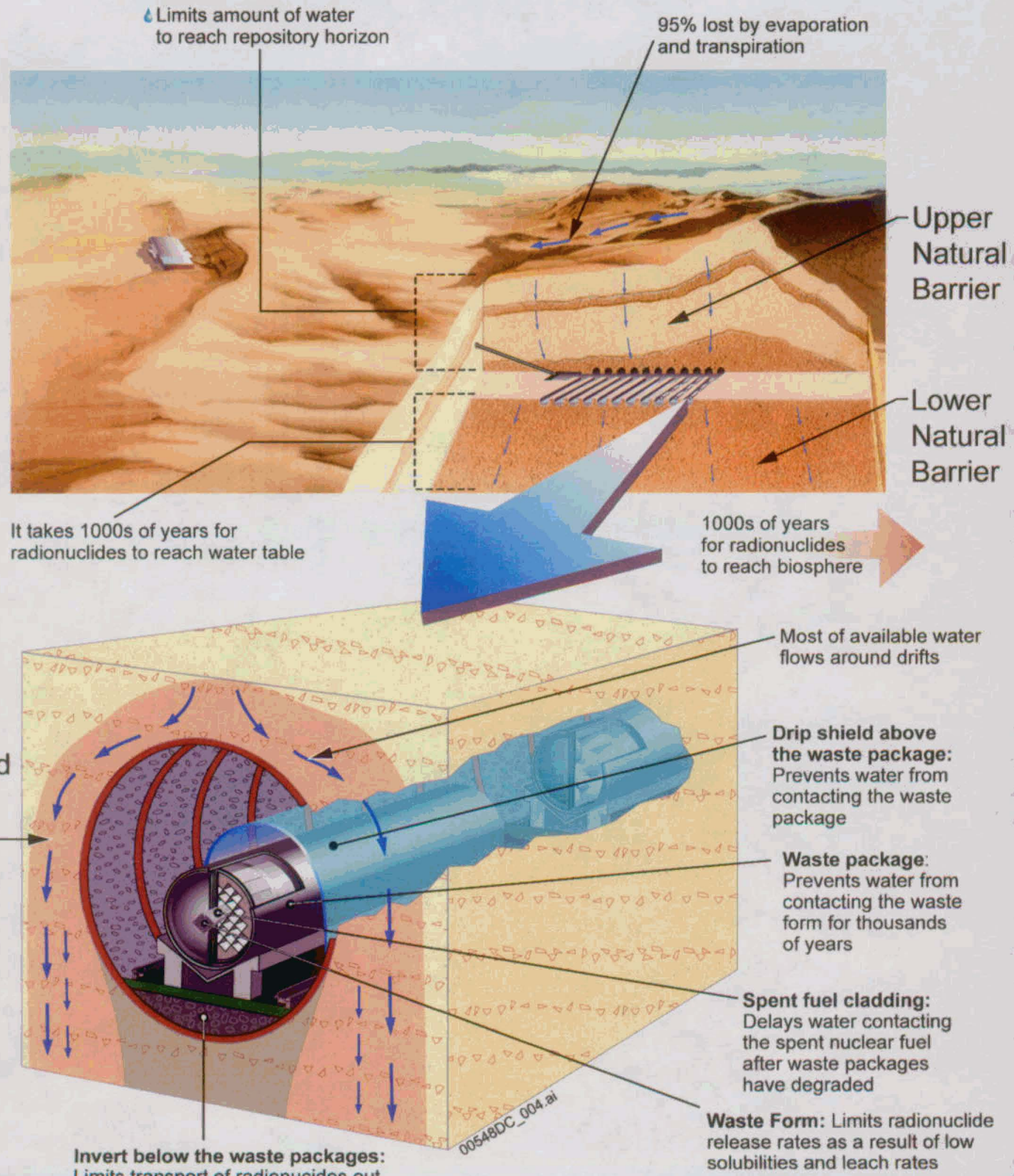

Limits transport of radionucides out solubilities and leach rates of the engineered barrier system 